\title{
PENCILS AND PHOTOS AS TOOLS OF COMMUNICATIVE RESEARCH AND PRAXIS
}

Analyzing Minga Perú's Quest for Social Justice in the Amazon

\section{Arvind Singhal and Elizabeth Rattine-Flaherty}

Abstract / The present article analyzes the communication for social change activities of Minga Perú, a non-governmental organization in the Peruvian Amazon. Minga Perú broadcasts a popular radio program, Bienvenida Salud (Welcome Health), in the Amazonas, and carries out several community-based empowerment activities for local women. The authors' data-collection procedures in the Peruvian Amazon included ordinary communicative tools, such as pencils and photographs. The respondents, comprising children and women, used these tools to 'visually' record their perceptions of Minga Perú contributions to reproductive health, gender equality and social change in the Peruvian Amazon. The authors argue that pencil sketches and photos represent important tools for communication research and praxis, providing an alternative to 'textocentrism' - the privileging of text, writing and the lettered word as a mode of comprehension and expression. However, in recognizing the value of visuals as an alternative mode of expression, the authors also point out that sketches, paintings and photographs are socially and technically constructed. That is, visual frames, by their very nature privilege the photographer's point of view.

Keywords / communication and change / community-based health promotion / entertainmenteducation / Minga Perú / participatory photography / social justice / visual voices

Consider the following two initiatives that employed pencils and photos, respectively, to gauge local realities, both based in Peru, but implemented some three decades apart:

Initiative No. 1: In September, 2003, while participating in a training workshop for community health promotoras (promoters) in the Peruvian Amazon, one of the present authors (born and raised in the American mid-west) used colored pencils as a communicative tool with the promotoras' children. Later, she made the following entry in her notebook:

I spend an hour drawing with the children. They are all very shy. ... Despite this 'shyness', the children warmed up to me during this sketching time. I drew pictures of things in my culture that I thought might interest them, and then explained to them [in Spanish] . . . I drew a picture of a snowman and explained to them that winter in my part of America is very cold, and that sometimes we have this white stuff called snow. I also told them many American children make snowmen during winter as a fun activity. I drew a pumpkin and explained the rituals of Halloween; a tree with multicolored leaves to talk about autumn; and sketched my 
house and cat to talk about my life in America. Some children approached me to show me their pencil drawings. I asked them to explain what they had drawn. Their sketches reflected their lives in the Amazon - pictures of the Amazon River, beaches, boats, fish farms, trees, butterflies, and animals. These pictures reflect what children considered important in their world.

Initiative No. 2: In 1973, while conducting a literacy project in a barrio of Lima, Peru, a team led by the noted Brazilian educator Paulo Freire (author of the seminal 1970 book Pedagogy of the Oppressed), asked people questions in Spanish, but requested the answers in photographs. When the question 'What is exploitation?' was asked, some people took photos of a landlord, grocer or a policeman (Boal, 1979: 123). One child took a photo of a nail on a wall. It made no sense to adults, but other children were in strong agreement. The ensuing discussions showed that many young boys of that neighborhood worked in the shoe-shine business. Their clients were mainly in the city, not in the barrio where they lived. As their shoeshine boxes were too heavy for them to carry, these boys rented a nail on a wall (usually in a shop), where they could hang their boxes for the night. To them, that nail on the wall represented 'exploitation'. The 'nail on the wall' photograph spurred widespread discussions in the Peruvian barrio about other forms of institutionalized exploitation, including ways to overcome them.

These two initiatives in Peru raise interesting possibilities about using ordinary communicative tools - such as pencils and photos - to understand local worldviews and realities. Employing these ordinary tools, we analyze a communication and social change initiative carried out by Minga Perú, a non-governmental organization in the Peruvian Amazon. Thrice a week, Minga Perú broadcasts a radio program, Bienvenida Salud (Welcome Health), in the Amazonas region, coupling it with community-based health promotion (through promotoras), and self-esteem training and income-generating activities for local indigenous and mestizo women. We argue that pencil sketches and photos represent important tools for communication research and praxis, providing an alternative to 'textocentrism' - the privileging of text, writing and the lettered word as a mode of comprehension and expression.

\section{Beyond Textocentrism: Alternative Ways of Knowing}

While knowledge can be generated in several ways, the predominant western route is based on scientific analysis, empirical observation and critical reflection. Such dominant knowledge is anchored in scientific paradigms and codified in print (Conquergood, 2002). What is not codified in print is usually repressed, disqualified and dismissed. Such unlettered 'subjugated knowledge' is not legible, and hence not considered legitimate (Foucault, 1980; Scott, 1998). The hegemony of 'textocentrism' is so strong that in the US, for instance, one of the most subjugated groups is the 'undocumented' immigrants (or 'illegal aliens'). They are people without papers; illegal because they are not legible (Certeau, 1984).

Western regimes of knowledge production have privileged the verbal and the written, and this point of view spread far and wide during centuries of colonialism 
(Conquergood, 2002; Hurston, 1990). In Belize, for instance, the Garifuna people, an African-descended minority group, use the word gapencillitin (literally 'people with pencil') to refer to the socioeconomic elites and intellectuals - the educated, literate and powerful individuals in society. The Garifuna use the term mapencillitin (literally 'people without pencil') to refer to the uneducated, rural and working class. Here, the pencil, as an instrument of print-based literacy, draws the line between the haves and have-nots (Conquergood, 2002).

However, a worldview constructed solely on the basis of print-based knowledge is limited and riddled with blind-spots: it privileges only those aspects that can be written down, leading to 'scriptcentrism arrogance' and 'textocentrism' (Burke, 1969; Williams, 1958). Textocentrism's problem is not the valorization of literacy, but the valorization of literacy to the exclusion of other forms of expression (Hurston, 1990). Textocentrism - not texts - is the problem. Disciplines are diminished when only one way of knowing is privileged (Conquergood, 2002). In recent decades, many have called for multiple and alternative ways of generating knowledge, including focusing on performances - artistic, musical and visual (Boal, 1979, 1998; Conquergood, 1988, 2002; Gramsci, 1971; Harter et al., in press; Mienczakowski and Morgan, 2001; Singhal, 2004; Singhal and Devi, 2003; Singhal et al., 2004; Singhal et al., in press;).

\section{Pencil Sketches as Agency}

For many people around the world, including a majority of the indigenous people who live in the Amazon rainforest of Peru, texts are inaccessible, remote and threatening. However, Amazonian people have a long tradition of expressing themselves in embroidery, paintings, sketches, handicrafts, dance, storytelling and musical performances. These performances, centering on artifacts and oral expression, represent spaces of agency and struggle for conscious, creative and critical expression. The Peruvian NGO Minga Perú (more on this organization later), in its motivational work with disempowered women of the Amazon, encourages women to use pencils to sketch out their gendered roles and identities. Topics that are difficult for women to speak out against, domestic violence, for instance, lend themselves to sketching. For instance, a sketch might show a women cowering in a corner - with eyes down, tightly clenched though muted lips, while her husband showers abuse - with his hands, words, eyes. These pencil sketches are then discussed to expose realms of male hegemony in the Amazon, raising critical consciousness about their rights as individuals, women and wives: for instance, the right to have a voice, the right to control their reproductive destiny and the right to earn an income. Pencils and markers in the Peruvian Amazon thus serve as alternative, non-textual tools of expression, creating new spaces for Amazonian women to reflect on their realities, gain self-esteem and enact agency. In essence, Minga Perú takes the pencil - a symbol of text, literacy and elitism (as it is for the Garifuna of Belize), and turns it on its head to privilege the creative expression of the unlettered, silenced and the marginalized. 


\section{Photographs as Agency}

For several decades, scholars and practitioners of visual sociology, visual anthropology and visual communication have had an interest in visual documentation and activism (Barnhurst et al., 2004; Griffin, 2001; Wang, 2003). Sociologists and anthropologists have used photographs to document social realities, looking at local communities as 'objects' of study. For instance, Gregory Bateson and Margaret Mead's 1942 book, Balinese Character, included 759 photographs to document Balinese life. The cultural meanings of the photographs were explained in the text. Documentary photographers and filmmakers have visually documented drugs and drug culture (Clark, 1971), the US civil rights movement (Hansberry, 1964), the antiVietnam War movement (Kerry, 1971), and the AIDS crisis, raising public awareness of these social issues. Photographs such as US Marines raising the flag on lowa Jima during the Second World War; the naked girl running to escape the Napalm attack during the Vietnam War; and Mandela's walk to freedom in South Africa are widely etched in a global collective memory (Hariman and Lucaites, 2002, 2003).

In contrast to the primary use of visuals for documentation, the relationship between the researcher and the subject is more dialogic, when employing the technique of photo-elicitation. In a typical photo-elicitation interview, a discussion is stimulated and guided by images (Collier, 1967). While the researcher takes pictures of the subject's world, it is the individual pictured (or an individual from the pictured world) who interprets the images, creating a 'listening' opportunity for the researcher.

However, an even more empowering, humane and participatory use of photographs is embodied in a strategy commonly referred to as 'photo voice', 'talking pictures' or 'visual voices'. In this technique, more generally known as 'participatory photography', cameras are put in the hands of the people, who are encouraged to document and co-share their own reality through photos (Singhal and Devi, 2003; Wang, 1999; Wang and Burris, 1994; Wang et al., 1996). The process of taking a photograph provides an opportunity to develop a story that was previously rejected, silenced, or overlooked. Further, the photograph's narrative becomes a participatory site for wider storytelling, spurring community members to further reflect, discuss and analyze the issues that confront them (Lykes, 1997; Wang, 2003).

Participatory photography has been utilized in varied settings with diverse populations, including the homeless in Ann Arbor, Michigan (Wang, 2003); peer educators for youth sexuality in Cape Town, South Africa (Moss, 1999); young homeless women in Detroit (Killion and Wang, 2000); with slum youth in Nairobi, Kenya; with disempowered rural women in Bihar, India (Singhal et al., 2004); and with street children in Guatemala (Gonzalez, 2003). The purpose of Fotokids in Guatemala, for instance, is to develop skills and self-esteem among children (Gonzalez, 2003). Founded in 1991 by Nancy McGirr, an American photojournalist, underprivileged Guatemalan children learn camera skills to shoot pictures, and to articulate their viewpoint through photos to community members. The work of Fotokids, which has since expanded to neighboring Honduras, has been exhibited in Britain, Germany and Spain, and featured in promotional campaigns for children's 
rights. Several 'Fotokids' are presently studying art, photography and journalism, having found an empowering way to express themselves.

Another notable example of participatory photography from Guatemala is PhotoVoice, a project of the Association of Maya Ixil Women, who live in the highlands of Guatemala. PhotoVoice has helped local Mayan communities to recover stories of its three-decade long internal war, reflect upon its debilitating effects and rebuild community (Lykes, 1997). Through photography, indigenous Mayan women developed a public record of their lives. PhotoVoice was inspired by the action-based participatory photography project conducted by rural Chinese women in Yunnan province (a photo-book called Visual Voices: 100 Photographs of Village China by the Women of Yunnan Province [1995] was compiled).

In sum, by placing pencils or cameras in the hands of people, a facilitator or researcher can gain insights into people's lived experiences, which were previously overlooked, rejected or silenced. The narrative of the sketch and the photograph can become a participatory site for wider storytelling, individual agency and community action. However, in analyzing sketches, paintings and photographs which are social and technical constructions - it is as important to foreground the absence of particular characters or scenes as it is to explicate what is present.

\section{Research Questions}

Our investigation of Minga Perú's activities in the Peruvian Amazon, employing pencil sketches and participatory photography, was guided by two research questions:

Research Question No. 1: How do our participants' pencil sketches depict their lived reality in the Peruvian Amazon, and speak to Minga Perú's influence on their community?

Research Question No. 2: How do our participants' photos allow them to coshare their reality in the Peruvian Amazon, and to talk about Minga Perú's influence on them and their community?

Before we describe our data-collection methods, and answer the research questions posed, a description of Minga Perú's social change initiatives is provided.

\section{Minga Perú: Seeking Social Justice in the Amazon}

Minga Perú, a non-governmental organization, was established in 1998 by Eliana Elías, a graduate of the Department of Social Communications from the University of Lima, and her husband, Luis Gonzalez, an Argentinean social worker who has worked in the Amazonas for over 15 years. ${ }^{1}$ Its objective was to improve the lives of people living in the Peruvian Amazon - one of the poorest, most inaccessible and most neglected regions in Peru (Elías, 2002). 'Minga' in the local language means 'collaborative community work', and Minga's interventions are consciously guided by a participatory communication framework (Table 1).

Minga's community-centered ameliorative activities are focused in the region of Loreto, a territory comprising one-quarter of Peru's geographic area, including 146,000 square miles of the Amazon rainforest (Sypher et al., 2002). About 1 
TABLE 1

Minga Peru's Theoretical Framework Reflects the Principles of Participatory Communication

Principles Underlying Participatory Communication

Horizontal lateral communication between participants

Process of dialog and democratic participation

Long-term process of sustainable change

Collective empowerment and decision-making

With community's involvement

Specific in content, language and culture

People's needs are the focus

Owned by the community

Consciousness raising

Source: Adapted from Gumucio Dagron (2001).

million people live in Loreto: half in lquitos City, the main city, and the other half in some 500 riverine communities ${ }^{2}$ along the Amazon River and its serpentine tributaries. Some 65 ethnolinguistic groups make up the Peruvian Amazon, representing a non-homogeneous population. The river is the main transportation channel and most people travel by manually powered shallow canoes made of balsa wood (Farrington, 2003). Steamers, ferries and motor boats connect major riverine routes along the Amazon. There are no roads in these remote communities, nor a dedicated power supply. Only a few health clinics exist, mostly located in bigger riverine communities or towns.

Minga promotes reproductive health, sexual rights, gender equality and income-generating activities in a region plagued by geographical isolation, poverty, disease and patriarchal traditions (Elías, 2002). Minga especially seeks to empower Amazonian women, who suffer from poor reproductive health, a repressive home environment and low self-esteem (Elías and Neira, 2004). In certain riverine communities, especially those inhabited by the Huambisa, Aguajun and ShipiboConibo ethnic groups, women may bear on average 10 children (three times the national average), lose one or two children to disease, perhaps contract a sexually transmitted infection, and die before reaching the age of 50 (22 years less than the national average) (Bustamente, 2004; Farrington, 2003).

Minga's programmatic activities in the Peruvian Amazon include the production and broadcast of a popular radio program called Bienvenida Salud (Welcome Health); the training of a cadre of community promotoras (promoters) who organize group listening sessions around Bienvenida Salud, and serve as local leaders for Minga's various health and community development activities; and on-the-ground, environmentally sustainable, income-generating activities through the establishment of fish farms, agro-forestry enterprises, small animal husbandry projects, as well as training in crocheting, sewing and carpentry to meet local needs. Minga's present work in the Peruvian Amazon is focused in the Marañon and El Tigre river 
basins (both represent major tributaries of the Amazon River and are easily accessible from Iquitos City, where Minga is headquartered).

\section{Bienvenida Salud: On-Air Intervention}

Bienvenida Salud, produced by Minga Perú, is a half-hour entertainment-education radio program broadcast three times a week (Monday, Wednesday and Friday) at 5:30 a.m. - the time when people are waking up in the Amazonas. Following the entertainment-education (E-E) strategy, Bienvenida Salud is purposely designed to both entertain and educate to increase audience members' knowledge about reproductive health, sexual rights and gender equality, creating favorable attitudes, shifting social norms and changing overt behavior (Singhal and Rogers, 1999, 2002; Sypher et al., 2002). By 2004, Minga Perú had broadcast over 900 episodes of Bienvenida Salud, earning audience ratings of between 45 and 50 percent among radio-owning households in the rural area of the Loreto region.

The mainstay of Bienvenida Salud is the lively banter between its two hosts Pashuca, who is a community health promotora, and Doña Rosa, her mother-inlaw. Throughout the program, Pashuca and Doña Rosa have a conflict-laden, intergenerational dialogue: Pashuca promotes gender equality, preventive health, family planning and rejects all forms of domestic violence; Doña Rosa, however, resists such changes. In a typical episode of Bienvenida Salud, these popular characters might discuss how pregnancy happens; how to prevent it; how to manage an abusive relationship; or what to do when your child has diarrhea (Farrington, 2003). In addition, Bienvenida Salud incorporates catchy jingles, music, informational spots, testimonials and contests to enhance its audience appeal.

The Bienvenida Salud stories are based on real-life events, and often sent to Minga by audience members as cards, hand-sewn letters, or even painted on bark. Vegetable, stone and natural colors are used as ink. To encourage audience feedback and formative inputs to designing Bienvenida Salud, Minga has made arrangements with boat companies to ferry listeners' letters from the interior of the Amazon jungle to lquitos City, where the headquarters of Minga is located. Letter-writers do not pay for this 'postal' service; Minga Perú pays a small fee for each letter that is delivered. When one of the present authors queried Eliana Elías, executive director of Minga Perú, about the reason for this emphasis on audience letters, she replied: 'Asking for letters is not only a strategy to measure audience effects, it is also a way to prepare the scripts of the programs and a way to change the passive consumers of the program into active producers' (personal conversation, 16 October 2002).

By 2004, Minga had received over 4000 audience letters. Audience members describe their personal problems, struggles and dilemmas with remarkable vividness and candor in these letters. For instance, in December 2002, Romel Castro wrote in about his abusive father: 'I suffered psychological abuse from my father. . . . He often came home drunk and would insult my mother and hit her. . . Sometimes I would see blood on her face. It's a big problem for me' (quoted in Farrington, 2003: 2).

Minga distills stories like the ones provided by Romel into a dialogue between Pashuca and Doña Rosa, and into short social dramas on Bienvenida Salud, each 
illustrating a carefully chosen topic for the episode, such as why eradicating violence in the community is important, or how to recognize the side-effects of contraceptive injections (personal conversation, Eliana Elías, 24 June 2004). The principal characters for the socio-drama are constant: Doña Rosa, the mother-in-law; her daughter-in-law, Pashuca; Pashuca's husband, Maximo; and their adolescent daughter Margarita. The language used in Bienvenida Salud is simple; technical terms are avoided (Farrington, 2003). Each show is taped and sent to local stations for rebroadcast. Tapes are also given to local school teachers as well as Minga Perú's community promotoras to play on audio-cassettes.

\section{Community Promotoras: On-the-Ground Interventions}

Complementing Minga's on-air broadcasts of Bienvenida Salud are a host of ongoing on-the-ground interventions, led by a trained cadre of community promotoras. Minga trains young women, using culturally appropriate materials, to work as health promoters and change agents in the communities where they live. They are carefully chosen on the strength of their personality, drive and motivation, and trained at the Tambo Minga training center, located two hours away by motorboat from lquitos City. 'Tambo' means a place of rest (or home) in Peruvian Spanish.

Overlooking the river near the town of Nauta, Tambo Minga includes a large dormitory with rows of bunk beds, a large circular hall, kitchen space, picnic tables and restrooms. Promotoras come here for training from various riverine communities, often accompanied by their children (and sometimes by their husbands) to learn the basics of male and female anatomy, detection of breast and cervical cancers, and simulation of the birth process (Farrington, 2003). They also implement sewing, weaving and crocheting projects; learn carpentry; how to establish and run a fish farm; how to grow medicinal herbs; and create environmentally sustainable ecosystems through agro-forestry and small animal husbandry projects. The promotoras return to the Tambo at least once a year for sharing experiences, and also for retraining. They represent Minga's partners and field-based change agents, modeling healthy reproductive lifestyles, initiating community discussions and projects, and serving as local resource persons for Minga's outreach. By 2005, 52 community health promotoras have been trained by Minga, who work closely with a network of 500 women in 35 riverine communities (of the Marañon and El Tigre river basins) in the Peruvian Amazon.

In sum, Minga Perú's work in the Peruvian Amazonas is geared toward empowering members of riverine communities, especially its women, to experience a higher quality of life; to make better informed choices with respect to their reproductive health; and to gain in self-esteem to value their sexual and human rights.

\section{Participatory Data Collection through Pencils and Photos}

In the present study, we privilege the reporting of the data collected using pencils and photos to analyze Minga Perú's on-air (Bienvenida Salud) and on-the-ground 
interventions. A participatory pencil sketching exercise was conducted with eight children of community promotoras to understand the salient aspects of their community life. In addition, a participatory photography exercise was undertaken with seven community promotoras to gauge their perception of Minga Perú's influence on their lives. However, the insights gleaned from these two participatory research activities were contextualized through a larger repertoire of data collected in the Peruvian Amazon over the past three years by the present authors, including field-based participant-observation (comprising a total of 75 person days) of Minga Perú's community-based activities conducted in October 2002, August to October 2003 and March, 2005.

\section{Pencil Sketches}

During the one week long training of community promotoras at the Tambo training facility in September 2003, one of the present authors handed out some blank sheets of paper and color pencils to eight children - a mixed-gender group representing sons and daughters of promotoras. As noted previously, pencil sketching was a fairly common activity in the Tambo, as community promotoras often sketched out their struggles, feelings and dilemmas - with respect to sensitive issues like domestic violence - in order to create opportunities for group discussion. So, blank sheets of paper and color pencils were easily available.

The eight Amazonian children sat on a picnic bench, spread their sheets of white paper in front of them, picked their favorite colors and began sketching in relative silence. One of the present authors sketched with them (as described at the beginning of this article), and periodically showed them her work (a snowman, a pumpkin and autumn leaves), making the children laugh and giggle. Then she asked the children to show her their sketches, and explain their drawings. The sketching exercise yielded a total of 11 colorful drawings. Once the children had finished drawing, and their explanations were noted, the present author asked for their permission to collect their work.

\section{Participatory Photography}

Disposable cameras were handed out (under the guidance of one of the present authors) in September 2003 to seven of Minga's community promotoras, each an avid listener of Bienvenida Salud. The purpose of our participatory photography exercise was to encourage the women community promotoras to capture - in photographs - the reality of Amazonian life, including their perceptions of Minga's influence on their communities. As opposed to asking the promotoras questions, and thereby constraining the nature and scope of their word responses, they were asked to capture Minga's influence on their community through the language of images. None of the seven promotoras had previously handled a camera; so each engaged in taking a 'test' picture (under the guidance of one of the present authors), becoming comfortable with the viewfinder, the shutter release and the flash button. The women were given two weeks to take pictures. 
Our 'shoot back' invitation to the seven promotoras, who hailed from four different riverine communities, yielded a total of 120 pictures. Some 13 photographs were discarded as they did not turn out (for example, because of insufficient lighting), or were duplicative, yielding a total data pool of 107 photographs. After developing these pictures, one of the present authors took the pictures back to each of the seven promotoras, asking them to narrate what the picture was depicting, what it meant to them, why they took it and so on. These narratives were taped with their permission, and subsequently translated and transcribed from Spanish to English.

\section{The Sketches Speak}

Research Question No. 1 asked: How do our participants' pencil sketches depict their lived reality in the Peruvian Amazon, and speak to Minga Perú's influence on their community?

The 11 children's drawings show a remarkable consistency of patterns and images. Almost all sketches show (1) neighborhoods - with houses, schools and churches, and paths crisscrossing between buildings, suggesting an active community life; and (2) natural elements - the sun, clouds, birds, the river, beaches, trees and butterflies, suggesting the close relationship of the Amazonian people with their natural habitat. For example, one pencil sketch shows a neighborhood with two colorful houses and a school (with a flag on top), all connected by paths; a river in the foreground (taking about a third of the page); 11 different kinds of trees, some laden with red and purple colored fruits, located by the side of the house and on the horizon; low-lying shrubs of six different colors interspersed with trees in a contoured landscape, suggesting an agro-forestry project; blue skies, and a patch of cloud floating above. The intersecting paths between homes, schools and churches point to connections between people who comprise these locations, revealing an early awareness among Amazonian children about interdependence and living communally. Further, the consistency of images suggests a commonly shared experience among the Amazonian children, even though they hail from different communities.

Interestingly, several sketches reflect societal changes that are directly attributable to Minga Perú's social interventions. These include sketches of chicken coops, fish farms and agro-forestry projects. These enterprises, all launched by Minga Perú, began in the Peruvian Amazon only in the past few years. For children to sketch these 'new' initiatives in their pictures on their own, without prompts, is noteworthy.

It seemed noteworthy that almost all of children's sketches were sketches of the outdoors, depicting what is generally understood as 'public' space. There were no sketches of what happens indoors, e.g. the nature of interactions among family members, including depiction of affection or abuse. In understanding visuals, it is perhaps as important to highlight the absence of particular scenes as it is to explicate what is present. Interestingly, as we have noted before, women's drawings in the Amazonas seem to more directed to exploring these 'indoor' interactions, including male hegemony and abuse. 


\section{The Photos Talk}

Research Question No. 2: How do our participants' photos allow them to co-share their reality in the Peruvian Amazon, and to talk about Minga Perú's influence on them and their community?

\section{Co-Sharing of Reality}

Several photographs allowed the women participants to co-share the reality of their lived experiences in the Amazon rainforest. Most of these photographs emphasized two dominant themes: (1) the centrality of the Amazon River (or one of its tributaries) in their lives - as a means of food, transportation and sustenance; and (2) patriarchal gendered roles in the Amazonas, ${ }^{3}$ including the disempowered position of the woman relative to men.

\section{Amazonian Aquaculture}

Several photographs depicted the Amazon River either in the foreground or the background (e.g. women washing dishes by the river), little paddle boats made of balsa (which serve as the primary mode of transportation), fishing nets lying on the ground (the tools of procuring food) and fish, the staple food and a major source of protein for the Amazonian people.

In one photograph taken by Nancy, a woman proudly holds a gleaming three foot long fish in her hand. Nancy commented: 'This here is a paiche, a fish that is loved and well-known in the Amazon. ... It is the richest and most delicious fish we have.' While few Peruvians may consider a fish to be an appropriate representation of their culture, Nancy felt it was most important to photograph. Further, people in the Amazonas have an uncanny ability to differentiate between the many varieties of available fish, knowing how they taste, how much they cost and how much they should weigh before being fished out of a fish farm. Clearly, the photographs depict the Amazonian aquaculture.

\section{Patriarchal Gendered Roles}

Several photographs depicted the subservient position of the Amazonian women relative to men, a situation that Minga Perú seeks to address. For instance, Adela's picture shows a middle-aged Amazonian woman and her husband sitting on their porch and having a conversation. The woman, sporting a forlorn expression, sits with her legs crossed while her husband stares directly into the camera, squatting with his arms and feet spread in an open position. Especially noticeable is the physical distance of about 10 feet that separates the woman and the man. When Adela was asked why she took the picture and why the man and woman were sitting so far apart, she noted: 'The woman is sitting at one side of the house and he is on the other and this was not anything unusual.' Upon probing, we learned that Amazonian men determine how close the couple sits. If they are sitting closer, and if the man has his arm around his partner, it is his decision to do so. This 
authority also applies to initiation of sex: the man determines if and when sex will happen.

Mari's picture of an Amazonian woman, shown in the company of two male family members, further reinforces the deeply entrenched patriarchal gender roles in the Amazon. Mari noted: 'During the taking of the picture, the woman didn't move but neither did she look at the camera.' In the photograph, the woman looks down, concentrating on her crocheting, avoiding the lens of the camera, and her body language reflecting a resigned posture. In contrast, the two males, with openchest postures, stare directly at the camera.

\section{Minga-Sparked Changes}

Most photographs, and their accompanying narratives, alluded to Minga's direct or indirect influence on the Amazonian communities. These photographs highlighted Minga's influence along five thematic domains: (1) the creative coupling of productive enterprises with community-based group listening to Bienvenida Salud; (2) the promotora as a spark plug for change in the community; (3) male co-option and involvement in community projects and reproductive health decisions (albeit on a limited basis); (4) improved family communication among listeners of Bienvenida Salud; and (5) the empowering aspects of letter-writing.

\section{Group Listening to Bienvenida Salud and Productive Enterprise}

Several photographs, in a single frame, captured the key interventional elements of Minga Perú's work in the Amazonian communities. For instance, Mercedita's photo shows a dozen community women making handicrafts out of chambira, a locally available fiber, while listening to an audiotaped episode of Bienvenida Salud. Mercedita, the locally based community promotora, who organized this group listening-cum-work session, noted: 'These are women who are making handicrafts. We called a meeting in the afternoon with all the community women so we could practice making crafts and listen to Bienvenida Salud.' After the episode ended, women discussed the content of the episode, and how it related to their lives. We see the importance of Bienvenida Salud's broadcasts, as well as Minga's strategy of handing out taped copies of the program episodes for promotoras to play in group settings, engendering discussion, reflection and possible action. Further, the accompanying activity of making handicrafts generates income for Amazonian women, enhancing their self and collective efficacy.

Juana's photo of half-a-dozen community women crocheting while listening to Bienvenida Salud also depicts the key elements of Minga's social enterprise in the Amazonian rainforest. As Juana, the community promotora, noted: 'Today we were crocheting with colored wool. These women are making baby booties to sell. Minga taught us how to use different patterns, so they are learning to crochet items that they can sell.' Here Juana is highlighting the practical and marketable skills that the women in her community have gained through Minga's interventions. By crocheting, Amazonian women can make clothes for their family - thus accruing savings 
- and also sell the product in the market to earn an income. Crocheting gives women the time to be mobile outside of their homes, gather socially at a central location, while both listening to and discussing an episode of Bienvenida Salud.

Interestingly, notably absent from these photos is the presence of men as group listeners of Bienvenida Salud. While they are frequently pictured engaging in community projects implemented by Minga (such as construction of fish farms), men do not appear to be part of the communal listening process.

\section{Promotoras, Spark Plugs for Change}

Adela, a community promotora, asked a friend to take a photo of half-a-dozen Amazonian women washing pots and pans by the river bank, with Adela in the center, leading a discussion of family violence within the community. Adela commented: 'Here we are washing dishes, women, adolescents and children - all together. I am there explaining what violence is. I'm reminding [the women] that we do not have to accept violence - physical, verbal, or emotional.' Here, we see the important role that community promotoras play in spurring on-the-ground community discussions, building on the on-air content of Bienvenida Salud. Adela's photo also demonstrates the strategic choice of location to discuss family violence. Men are absent when women are washing dishes by the river bank, so this location represents a 'safe' environment for women to talk freely. The photo also shows the advantages of a having a community promotora from within the community. Her local presence means she is always on duty, improvising as needed, and capitalizing on opportunities when they come along to make her move. This photo also shows the complexity of social change processes: women find ways to collectively discuss oppressive social norms, aided by a peer change agent, but do so in the safety of 'their' space, and within the confines of their traditional roles.

\section{Male Involvement}

Several photographs show certain degrees of male involvement in Minga's social enterprises, including men helping in the construction of fish farms, chicken coops and in implementing agro-forestry. Mari's picture shows a fish farm in which men are in the water with fishing nets while women are on higher ground. Mari noted: 'When we have a project like making a fish farm which requires us to clear land, men always help us.... Constructing a fish farm isn't easy, you have to clear the earth, pull out the trees. ... This is hard work, and you have to be very strong.' Given that fishing is predominantly a male-centered activity in the Amazon, Minga strategically chose fish farming as one of its social enterprises for it helps to routinize men's involvement in community development projects. The women are usually responsible for feeding the fish, in weighing and measuring them, and in selling them in the market. Minga has learned that such a joint partnership between men and women in an incomegenerating activity fosters family and community cohesion.

Interestingly, while Minga estimates that men constitute some 30 percent of Bienvenida Salud's regular listenership, they do not show up in the photographs as 
participants in a group listening situation. Most group listening situations comprised of women and children. So, in essence, the circumstance in which listening occurs for men and women seems to vary considerably. Some men, for instance, may fear being perceived as 'weak' among their peers if they listened to a program that espouses women's equality. However, these male listeners, often accompanied by their spouses, are also involved by community promotoras in discussions about family size. In a photograph taken by a friend of Adela, a community promotora, Adela is shown talking to several community members about family planning. Fishing nets surround the area where the group is conversing. Adela noted: 'Here I am giving a talk about family planning. The man also wants to learn more about how to plan his family size. It is not only women who are interested in family planning, but some men also.' However, to not overstate the reality, Adela promptly added: 'Family planning is still largely the responsibility of the woman because many [Amazonian] men don't want to deal with it.' Alas, social norms shift gradually.

\section{Improved Family Communication}

Several photographs depicted improved family communication, especially between parents and children, in households that listen to Bienvenida Salud and those that are visited by the local community promotora. In Nancy's photograph, for instance, we see a gathering of several Amazonian mothers and their adolescent daughters. Nancy, the promotora, commented: 'I had this meeting so the mothers don't have any doubt about letting their daughters attend my meetings. The mothers should also know what their daughters are learning.' Through such mother and daughter gatherings, promotoras earn the trust of both generations, encouraging more open communication between them. In the Amazonas, pointed communication between mothers and daughters about reproductive health issues is not normative.

Juana's photo shows an avid woman listener of Bienvenida Salud talking with her children during dinner. Juana noted: 'This woman is talking with her two boys. . . . Many children here grow up to be delinquents, so she is telling them that when they grow up they shouldn't follow that example. She emphasizes the need for them to be well-behaved children and adolescents.' So through its on-air broadcasts of Bienvenida Salud, and the on-the-ground activities of its promotoras, Minga emphasizes more open communication between parents and children.

\section{Listeners as Producers}

Several photographs showed Bienvenida Salud listeners writing letters to Minga to provide feedback, share their personal dilemmas and to shape the content of future episodes. A picture taken by Nancy, the local promotora, shows 10 adolescent girls, between the ages of 12 and 14, sitting around a table writing letters to Minga Perú, immediately after listening to an audiotaped episode of Bienvenida Salud. The audiotape player is prominently located in the centre of the table. Nancy noted: 'The girls are learning how to write letters. Previously, they really didn't know how to write letters and so I'm teaching them how to go about writing one.... They 
really like talking about Bienvenida Salud, and they're disappointed that we've almost finished the cassette tapes (that Minga lent us). There is just one more left to listen to.'

Minga encourages letter-writing by Bienvenida Salud's listeners, covering the costs for the letters to be ferried to lquitos City, and reading portions from them during the broadcasts. Letter-writing provides a forum for adolescent girls, like the ones in Nancy's photo, to practice writing skills, openly express their thoughts and feelings and gain self-esteem, realizing their expressions are valued. Letters allow Minga to be in tune with the lives of teen girls in the Amazon, and allow (passive) listeners to become (active) message producers.

\section{Conclusions}

The present article argues that ordinary communicative tools - such as pencils and photos - can provide rich, descriptive insights into local worldviews and realities, serving as instruments of both research and praxis. We employed pencil sketching with children and participatory photography with women to analyze the quest of Minga Perú to foster reproductive health, sexual rights and gender equality in the Peruvian Amazon. In privileging visual forms of expression, we questioned the dominant hegemony of textocentrism that legitimizes the lettered, literate and textbased ways of knowing. Our research sought to validate other, non-textual ways of knowing by privileging the performative dimensions of sketches and photographs.

The pencil sketches drawn by children depicted a strong sense of neighborhood and community life in the Peruvian Amazon, as also the close relationship of people with nature. The sketches also flagged certain social enterprises - chicken coops, fish farms and agro-forestry - that are directly attributable to Minga Perú's interventions.

The photographs taken by women community promotoras highlighted the aquaculture of the communities, centering around the Amazon River, and emphasized entrenched patriarchal gendered roles in the Amazonas. However, a majority of the photographs pointed to Minga's influence, both direct and indirect, on the Amazonian communities. Minga's influence was reflected in photographs that showed how crocheting and handicraft production was integrated with communitybased group listening to Bienvenida Salud; how the promotora served as a change agent in the community; how Minga's activities fostered male involvement in community projects, such as in the establishment of fish farms; how listening to Bienvenida Salud promoted better parent-to-child communication; and how letterwriting made radio listeners active participants in producing or shaping media messages.

However, for visuals to become truly participatory, it is important that the participants not only make sketches and take photos and share their stories with the researcher (as was the case in the present research), but also share their stories with other community members, concerned citizens and policy-makers. We recommend that for participatory sketching and photography interventions, participants share their sketches and photos and their narratives with other community members 
to further gauge the commonality and differences of their meanings and interpretations. These community discussion sites can then also serve as a catalyst for community decisions and actions.

Participatory sketching and photography, the drivers of the present research investigation, lie at the interface of theory, method and praxis (see also Morphy and Banks, 1997). A methodological tool in practice cannot be theoretically neutral since it is aligned with the objectives of the research and privileges the researchers' biases (Singhal et al., in press). In taking stock of the sociology of visuals - whether in the form of sketches or photos - it is not difficult to discern the obvious conclusion: almost all paintings, sketches and photos are usually produced by 'the powerful, the established, the male, the colonizer' to 'portray the less powerful, less established, female, and colonized' (Harper, 1994: 408). We advocate handing over the means of visual production to the oppressed, the silent and the muted.

While recognizing that visuals allow the 'oppressed' to make statements that are not possible by words, we should also remember that all sketches, paintings and photographs are socially and technically constructed (Harper, 1994). Thus it is as important to foreground the absence of particular characters or scenes as it is to explicate what is present. Further, photography is by its very nature, more 'active' and 'intrusive' than simple observation (i.e. methodological 'representation' to build theory). In essence, despite the dictum 'seeing is believing', visual frames are a reflection of the photographer's point of view, biases and knowledge. They are no less and no more.

\section{Notes}

The present research owes a debt of gratitude to Minga Perú staff members, who opened their offices, archives, studios and their hearts for us to undertake this research journey. We especially acknowledge Eliana Elías, executive director of Minga Perú, Luis Gonzalez, Everly Egoavil, Rosa Nilson, Mar'a Isabel Tafur, Rosario Avellaneda, Marcela Retamozo, Enrique Agnini, Eloy Neira and Juan Nashnate. We also acknowldege Dr Lynn Harter, School of Communication Studies, Ohio University for commenting on a previous version of this manuscript.

1. Minga Perú started its work in the Peruvian Amazon in collaboration with the Amazonian Peoples' Resources Initiative (APRI) of the University of Kansas. Currently, Minga works independently of APRI. Minga's work is supported by the Ford Foundation, the American Jewish World Service, AVINA Foundation, Empower, Moriah Fund and Match International.

2. These numbers pertain to officially recognized riverine communities. The actual number is higher.

3. There are many gendered and patriarchal systems operating in the Peruvian Amazonas, and the present investigation, at best, only captures a slice of it.

\section{References}

Barnhurst, K.G., M. Vari and I. Rodriguez (2004) 'Mapping Visual Studies in Communication', Journal of Communication 54(4): 616-44.

Bateson, G. and M. Mead (1942) Balinese Character: A Photographic Analysis. New York: New York Academy of Sciences.

Boal, A. (1979) The Theatre of the Oppressed. New York: Urizen Books.

Boal, A. (1998) Legislative Theater. New York: Routledge. 
Burke, K. (1969) A Rhetoric of Motives. Berkley: University of California Press.

Bustamente, C. (2004) 'Saludes públicas y salud reproductiva en la Amazonía', pp. 269-81 in E. Elías and E. Neira (eds) Salud reproductiva en la Amazonía: perspectivas desde la cultura, el género y la comunicación. Lima: Minga Perú.

Certeau, M. (1984) The Practice of Everyday Life, trans. Steven Rendell. Berkeley: University of California Press.

Clark, L. (1971) Tulsa. New York: Lunstrum.

Collier, J., Jr (1967) Visual Anthropology: Photography as a Research Method. New York: Holt, Rinehart and Winston.

Conquergood, D. (1988) 'Health Theater in a Hmong Refugee Camp', The Drama Review: A Journal of Performance Studies 32: 174-208.

Conquergood, D. (2002) 'Performance Studies: Interventions and Radical Research', The Drama Review: A Journal of Performance Studies 46(2): 145-56.

Elías, E. (2002) 'Comunicar para icarar: el modelo Minga de comunicación para la salud desde la cultura', paper presented at the International Conference on Reproductive Health in the Amazonian Region, Iquitos, Peru, October.

Elías, E. and E. Neira (eds) (2004) Salud reproductiva en la Amazonía: perspectivas desde la cultura, el género y la comunicación. Lima: Minga Perú.

Farrington, A. (2003) '“Family Matters" in the Amazon', Ford Foundation Report 34(4): 16-19.

Foucault, M. (1980) Power/Knowledge. New York: Pantheon.

Freire, P. (1970) Pedagogy of the Oppressed. New York: Continuum.

Gonzalez, D. (2003) 'Young Lives Transformed, Guided by a Camera Lens', The New York Times 7 May: 1 and 5 .

Gramsci, A. (1971) Selections from the Prison Notebooks. New York: International.

Griffin, M. (2001) 'Camera as Witness, Image as Sign: The Study of Visual Communication in Communication Research', Communication Yearbook 24: 432-63.

Gumucio Dagron, A. (2001) Making Waves: Stories of Participatory Communication for Social Change. New York: The Rockefeller Foundation.

Hansberry, L. (1964) The Movement. New York: Simon and Schuster.

Hariman, R. and J.L. Lucaites (2002) 'Performing Civic Identity: The Iconic Photograph of the Flag Raising In lowa Jima', Quarterly Journal of Speech 88: 363-92.

Hariman, R. and J.L. Lucaites (2003) 'Public Identity and Collective Memory in US Iconic Photography: The Image of "Accidental Napalm"', Critical Studies in Mass Communication 20: 35-66.

Harper, D. (1994) 'On the Authority of the Image: Visual Methods at the Crossroads', pp. 403-12 in N.K. Denzin and Y.S. Lincoln (eds) Handbook of Qualitative Research. Newbury Park, CA: Sage.

Harter, L.M., D. Sharma, S. Pant, A. Singhal and Y. Sharma (in press) 'Catalyzing Social Reform through Participatory Folk Performances in Rural India', in L. Frey and K. Carragee (eds) Communication and Social Activism. Cresskill, NJ: Hampton Press.

Hurston, Z.N. (1990) Mules and Men. New York: Harper.

Kerry, J. (1971) The New Soldier. New York: Macmillan.

Killon, C. and C.C. Wang (2000) 'Linking African-American Mothers across Life Stage and Station through Photovoice', Journal of Health Care for the Poor and Underserved 11: 310-25.

Lykes, M.B. (1997) 'Activist Participatory Research among the Maya of Guatemala: Constructing Meanings from Situated Knowledge', Journal of Social Issues 53(4): 725-46.

Mienczakowski, J. and S. Morgan (2001) 'Ethnodrama: Constructing Participatory, Experiential and Compelling Action Research through Performance', pp. 219-27 in R. Reason and H. Bradbury (eds) Handbook of Action Research: Participative Inquiry and Practice. Thousand Oaks, CA: Sage. Morphy, H. and M. Banks (1997) 'Introduction: Rethinking Visual Anthropology', pp. 1-35 in H. Morphy and M. Banks (eds) Rethinking Visual Anthropology. New Haven, CT and London: Yale University Press.

Moss, T. (1999) 'Photovoice', Children First 3(26): 28-9.

Scott, J.C. (1998) Seeing Like a State. New Haven, CT: Yale University Press.

Singhal, A. (2004) 'Entertainment Education through Participatory Theater: Freirean Strategies for Empowering the Oppressed', pp. 377-98 in A. Singhal, M. Cody, E.M. Rogers and M. Sabido (eds) Entertainment-Education and Social Change: History, Research, and Practice. Mahwah, NJ: Lawrence Erlbaum. 
Singhal, A. and K. Devi (2003) 'Visual Voices in Participatory Communication', Communicator 37: $1-15$.

Singhal, A. and E.M. Rogers (1999) Entertainment-Education: A Communication Strategy for Social Change. Mahwah, NJ: Lawrence Erlbaum.

Singhal, A. and E.M. Rogers (2002) 'A Theoretical Agenda for Entertainment-Education', Communication Theory 12(2): 117-35.

Singhal, A., D. Sharma, M.J. Papa and K. Witte (2004) 'Air Cover and Ground Mobilization: Integrating Entertainment-Education Broadcasts with Community Listening and Service Delivery in India', pp. 351-74 in A. Singhal, M. Cody, E.M. Rogers and M. Sabido (eds) EntertainmentEducation and Social Change: History, Research, and Practice. Mahwah, NJ: Lawrence Erlbaum.

Singhal, A., L.M. Harter, K. Chitnis and D. Sharma (in press) 'Shooting Back: Participatory Photography in Entertainment-Education', Black Praxis.

Sypher, B.D., M. McKinley, S. Ventsam and E. Elías (2002) 'Fostering Reproductive Health through Entertainment-Education in the Peruvian Amazon: The Social Construction of Bienvenida Salud!', Communication Theory 12(2): 192-205.

Visual Voices: 100 Photographs of Village China by the Women of Yunnan Province (1995) Yunnan, China: Yunnan People's Publishing House.

Wang, C. (1999) 'PhotoVoice: A Participatory Action Research Strategy Applied to Women's Health', Journal of Women's Health 8(2): 185-92.

Wang, C. (2003) 'Using Photovoice as a Participatory Assessment and Issue Selection Tool: A Case Study with Homeless in Ann Arbor', pp. 179-95 in M. Minkler and N. Wallerstein (eds) Community-Based Participatory Health Research. San Francisco, CA: Jossey-Bass.

Wang, C. and M. Burris (1994) 'Empowerment through Photo Novella: Portraits of Participation', Health Education Quarterly 21(2): 171-86.

Wang, C., M. Burris and Y.P. Xiang (1996) 'Chinese Village Women as Visual Anthropologists: A Participatory Approach to Reaching Policy-Makers', Social Science and Medicine 42(10): 1391-400.

Williams, R. (1958) Culture and Society. New York: Columbia University Press.

Arvind Singhal is professor of communication studies and presidential research scholar at Ohio University, where he teaches and conducts research on the role of communication in organizing for social change and the entertainmenteducation communication strategy. He is author or editor of several books, including Communication of Innovations: A Journey with Ev Rogers (Sage, forthcoming); Organizing for Social Change: A Dialectic Journey of Theory and Practice (Sage, 2006), Entertainment-Education and Social Change: History, Research, and Practice (Lawrence Erlbaum, 2004), Combating AIDS: Communication Strategies in Action (Sage, 2003) and Entertainment-Education: A Communication Strategy for Social Change (Lawrence Erlbaum, 1999)

Address School of Communication Studies, Lasher Hall, Ohio University, Athens, $\mathrm{OH}$ 45701, USA. [email: singha/@ohio.edu]

Elizabeth Rattine-Flaherty is a second year doctoral student in the School of Communication Studies at Ohio University, pursuing a degree in health communication with an emphasis on women's issues and Latin America. Specifically she is interested in how mass-mediated strategies such as entertainmenteducation can be combined with grassroots organizing to empower traditionally marginalized communities.

Address School of Communication Studies, Lasher Hall, Ohio University, Athens, OH 45701, USA. [email: er192099@ohio.edu] 